\title{
The role of melanism in oncillas on the temporal segregation of nocturnal activity
}

\author{
Graipel, ME. ${ }^{a *}$, Oliveira-Santos, LGR. ${ }^{a}$, Goulart, FVB. ${ }^{a}$,Tortato, MA. ${ }^{a}$, \\ Miller, PRM. ${ }^{a}$ and Cáceres, $N C .^{b}$

\begin{abstract}
aprojeto Parques e Fauna, Laboratório de Ecologia Terrestre Animal, Departamento de Ecologia e Zoologia, Centro de Ciências Biológicas, Universidade Federal de Santa Catarina - UFSC, Campus Universitário, s/n, Sala 007, Bloco B, Térreo, Córrego Grande, CEP 88040-900, Florianópolis, SC, Brazil

bLaboratório de Ecologia e Biogeografia, Departamento de Biologia, Centro de Ciências Naturais e Exatas, Universidade Federal de Santa Maria - UFSM, Prédio 17, Cidade Universitária, Camobi, Km 9, CEP 97110-970, Santa Maria, RS, Brazil

*e-mail: graipel@ccb.ufsc.br
\end{abstract}

Received: July 17, 2012 - Accepted: June 10, 2013 - Distributed: November 30, 2014

(With 3 figures)

\begin{abstract}
The occurrence of coat colour polymorphisms in populations may promote the ecological success of species by permitting a wider spectrum of use of different subsets of available resources. We conducted an analysis of temporal segregation by comparing night brightness with nocturnal activity of spotted and melanistic oncillas (Leopardus tigrinus). Melanistic oncillas were more active during bright nights and spotted oncillas and other species were more active during dark nights. Each colour morph occupied a temporal niche outside the confidence interval of the other colour morph, demonstrating the ecological significance of polymorphic colour patterns in this felid species.
\end{abstract}

Keywords: Leopardus tigrinus, activity, moonlight, camera trap.

\section{O papel do melanismo na segregação temporal da atividade noturna do gato-do-mato-pequeno}

\begin{abstract}
Resumo
A ocorrência de polimorfismo no padrão de pelagem de populações pode promover o sucesso ecológico das espécies por permitir um amplo espectro de uso de diferentes parcelas de recursos disponíveis. Nós testamos a existência de diferença na segregação temporal do gato-do-mato-pequeno (Leopardus tigrinus), comparando a luminosidade durante períodos de atividade noturna de indivíduos pintados e melânicos. Indivíduos melânicos de gato-do-mato-pequeno foram mais ativos durante noites claras e indivíduos pintados de gato-do-mato-pequeno e outras espécies foram mais ativas durante noites escuras. Cada forma de coloração ocupou um nicho temporal fora do intervalo de confiança do outro, demonstrando a significância ecológica dos padrões de polimorfismo de colorações nesta espécie de felino.
\end{abstract}

Palavras-chave: Leopardus tigrinus, atividade, luminosidade da lua, armadilha fotográfica.

\section{Introduction}

Melanism is a ubiquitous phenomenon in the animal kingdom that has been used to investigate evolutionary shifts (Majerus and Mundy, 2003). Most mammal species possess variations in coat colour within populations, but only a few species exhibit discontinuous variations (Majerus and Mundy, 2003). Eleven out of 38 felid species carry mutations that increase the amount of melanin, resulting in black or nearly black coats of melanistic individuals that coexist with wild-type individuals with spotted or uniform tan coat colours. Top cats such as the jaguar Panthera onca (Linnaeus), or small cats such as the domestic cat Felis silvestris catus, exhibit melanism in high frequencies in some populations and hence it is apparently adaptative in nature (Eizirik et al., 2003). Similar to other animal groups (invertebrates, reptiles and birds), this polymorphism has originated several times independently in felids. However, the functional advantages of melanism remain an open field for empirical and theoretical development (Caro, 2005). While the genetic and molecular basis of melanism in mammals have been clarified (Nachman et al., 2003; Eizirik et al., 2003), we have little evidence linking the genetic information to maintenance of the melanistic phenotype in the wild. The melanistic phenotype must bring adaptative advantages. Therefore, ecological information 
about polymorphic individuals in the wild will be determinant in the understanding of the genetic maintenance of these polymorphisms.

The increase in the frequency of the black moth after industrialisation (Grant et al., 1996; Majerus, 1998), and its decline after air quality improvement (Saccheri et al., 2008) are emblematic examples of natural selection decreasing or increasing predation rates of the different colour forms. Desert rodent species that present intraspecific coat colour variation show a strong correlation between their coat colour and the substrate colour, and this camouflage is an adaptive phenotype against predation by rapine birds (reviewed by Majerus and Mundy, 2003). Hoekstra and Nachman (2003) have demonstrated the link between genotype and phenotype in these rodents, where black rodents in dark substrate habitat present high frequency of the mutated alleles responsible for melanism. In contrast to moths and desert rodents, the adaptive benefits of melanism in felids remain obscure.

Forsman et al. (2008) hypothesised that the evolutionary persistence of polymorphisms in populations is because they promote the ecological success of species by permitting the use of a wider spectrum of available resources. This hypothesis argues that behavioural observations of resource use by individuals that belong to different colour morphs will demonstrate that each morph explores different niche dimensions. Thus, we conducted a test for temporal segregation by melanistic and spotted oncilla Leopardus tigrinus (Schreber), one of the smallest spotted wild cats of America, which has a silhouette and size resembling a house cat (Nowell and Jackson, 1996). We compared the temporal segregation of nocturnal activity by lunar brightness for each colour morph using the largest known sample of melanistic individuals of L. tigrinus. We expected that moon brightness has some role in the activity pattern of melanistic L. trigrinus. So we expect that one of the two morphs of this felid species could be favoured by the brightness of moonlight, in this case, the melanistic form. It is known that moonlight influences the activity of some mammal species like marsupials (Julien-Laferrière, 1997) and bats (Esbérard, 2007). In this sense, we expected something similar to L. tigrinus, related to frequency of coat colour and moonlight.

\section{Material and Methods}

Between January 2005 and July 2009 the activity of oncillas was recorded by remote camera traps $(n=30$; Tigrinus $\left({ }^{\circledR}\right)$ in a sampling effort of 8,500 trap-days in four areas inside two Tropical Rain Forest Reserves in southern Brazil (Caraguatá Ecological Reserve: $27^{\circ} 27^{\prime} \mathrm{S}$, 48 57'W - 4,200 ha; Serra do Tabuleiro State Park: $28^{\circ} 26^{\prime} \mathrm{S}, 48^{\circ} 50^{\prime} \mathrm{W}-85.000 \mathrm{ha}$ ). A detailed description of the study areas and sampling method is available in Goulart et al. (2009). We compared the distribution of the circadian activity pattern of spotted and melanistic morphs using Watson's $U^{2}$ Test for circular data, using the Oriana 3.0 software. We considered only records taken one hour apart as independent. The percentage of nocturnal brightness was obtained by Moonrise 3.5 software for each nocturnal independent record, discarding crepuscular records. Nocturnal records obtained before moonrise and after moonset were considered zero percent brightness. Nebulosity data were obtained in a meteorological station $40 \mathrm{~km}$ far from our study area, which is an index varying from 0 to 10 .

Differences between brightness associated with activity of spotted and melanistic morphs, and other wild felid species and small mammals [rodents and Philander frenatus (Olfers, 1818)] captured during the sampling effort, were compared by analysis of variance. In addition, we used the logistic regression to test the relationship between each record of melanistic/spotted animal (binary variable) with moon brightness and nebulosity.

\section{Results}

We recorded 170 independent observations of oncillas, 139 of spotted and 31 of melanistic forms (Figure 1). Additionally, we recorded 15 independent nocturnal brightless observations of margay, 35 of ocelot, 19 of cougar and 132 of small mammals.

There was no trend towards either nocturnal or diurnal activity of oncillas (Figure 2), and there was no difference in the distribution of arrhythmic activity patterns between spotted and melanistic forms (Watson's $U^{2}$ test $=0.056$; $n 1=31 ; n 2=139 ; P>0.5)$ (Figure 2$)$.

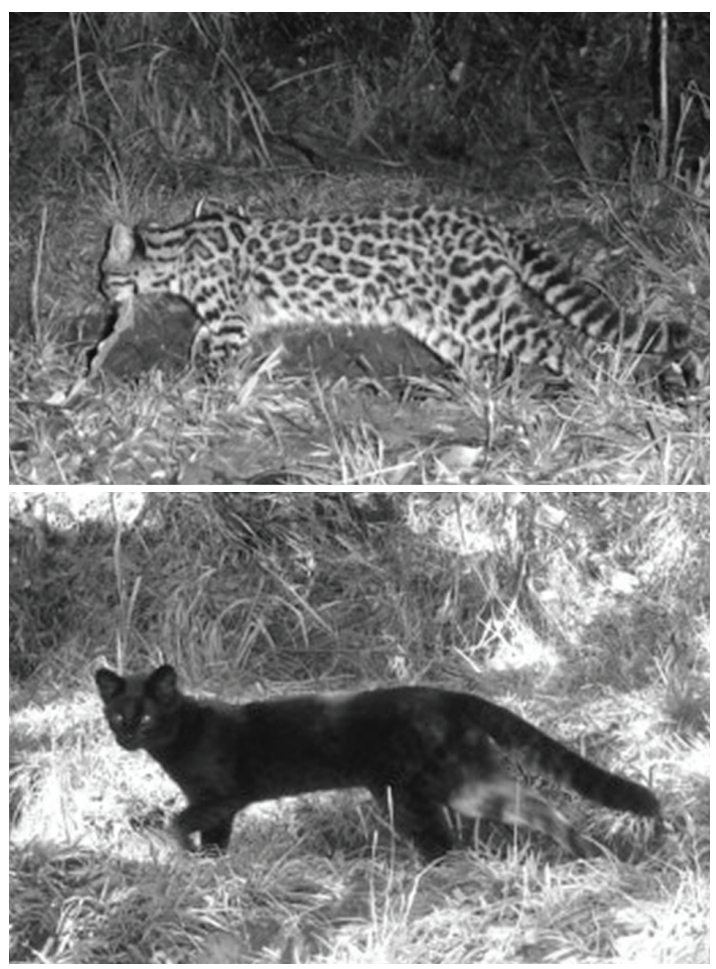

Figure 1. Spotted (top) and melanistic (bottom) oncillas recorded by camera-traps. 
However, melanistic oncillas were more active during bright nights (mean nocturnal brightness $=75.3 \% ; n=11$; $S E=10.1 ; C I=55.5-95.0$ ) than spotted oncillas (mean nocturnal brightness $=38.5 \% ; n=67 ; S E=5.0 ; C I=28.8$ -48.2 ), and the activity of melanistic oncillas was also significantly higher during bright nights than other wild felid species, L.wiedii (Schinz), L. pardalis (Linnaeus,), and Puma concolor (Linnaeus), and small mammals $(F=2.601 ; P=0.025)$ (Figure 3$)$.

The multiple logistic regression between melanistic and spotted frequencies with regard to moon brightness and nebulosity confirmed the same relationship above, being significant $\left(X^{2}=7.71 ; \mathrm{df}=2 ; \mathrm{p}=0.021\right)$; however, only brightness contributed to explain melanistic and spotted frequencies in simple analysis $\left(\mathrm{X}^{2}=7.35\right.$; $\mathrm{df}=1$;

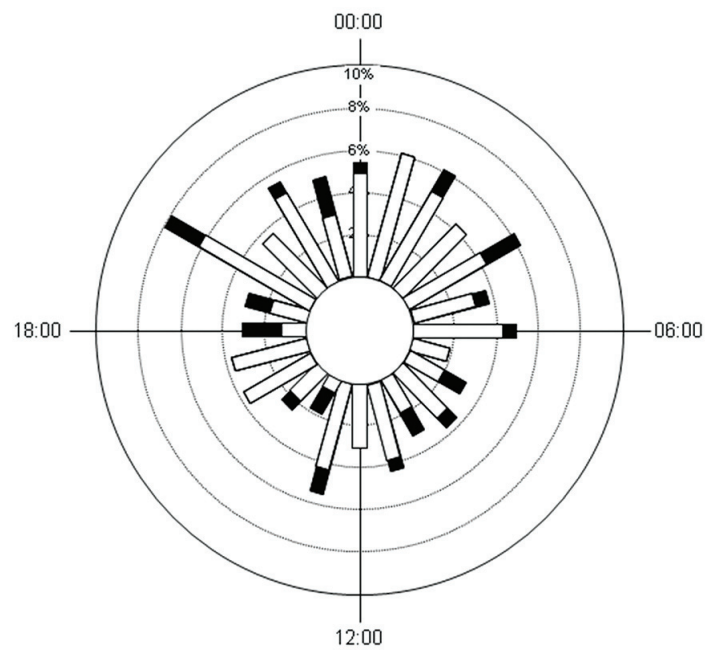

Figure 2. Circadian activity of oncillas in Atlantic Rain Forest of southern Brazil. White bars represent registers of spotted $(n=139)$, and black bars, registers of melanistic oncillas $(\mathrm{n}=31)$.

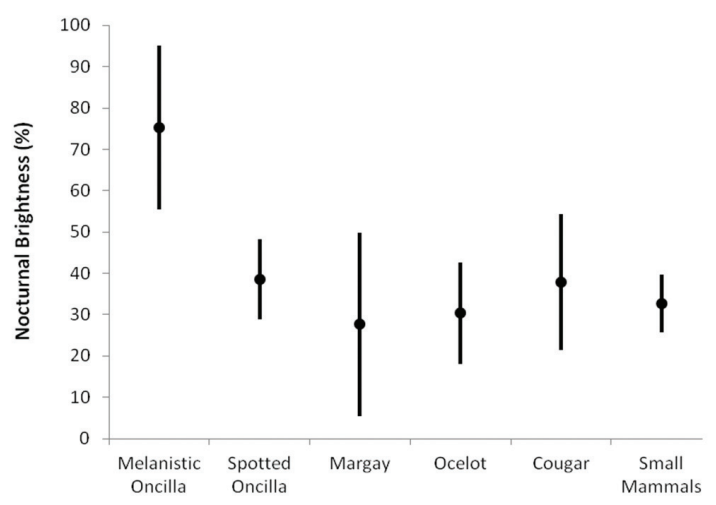

Figure 3. Activity of melanistic oncilla $(\mathrm{n}=11)$, spotted oncilla $(n=67)$, margay $(n=15)$, ocelot $(n=35)$, cougar $(n=19)$ and small mammals $(n=132)$ regarding nocturnal brightless (mean $\pm 95 \%$ IC) in Atlantic Rain Forest of southern Brazil. $\mathrm{p}=0.007$ for moon brightness, and $\mathrm{X}^{2}=0.17 ; \mathrm{df}=1$; $\mathrm{p}=0.687$ for nebulosity).

\section{Discussion}

Oncillas presented arrhythmic activity pattern similar to that obtained by Tortato and Oliveira (2005) and Oliveira-Santos et al. (2012) for the same region and species. However, the latter authors recorded variations in activity distribution of oncillas associated with the presence of other felid species.

Individuals from a single population may differ in several aspects in the use of resources, for instance, between sexes (Schoener, 1967), age-group (Cordero and Nicolas, 1987) and among trophic polymorphic individuals (Swanson et al., 2003). The temporal segregation between different colour coat phenotypes observed in our study corroborates Forsman's prediction of the ecological significance of polymorphic colour patterns (Forsman et al., 2008). In the partitioning of resources between and within species, food and habitat sources are considered more important than the daily distribution of activity (Schoener, 1974). On the other hand, the activity pattern through interference competition increases in importance (Carothers and Jaksic, 1984), because territorial Neotropical carnivores could present potentially lethal damage between each other (Palomares and Caro, 1999; Di Bitetti et al., 2009).

Melanistic individuals could be more effectively cryptic on bright nights than spotted individuals. According to our data, the space and the food resources available during bright nights are under-explored by other nocturnal predators present in the study area (e.g. L. wiedii, L. pardalis and Puma concolor). Most rodents, the main prey consumed by oncillas and other felid competitors (Oliveira et al., 2010), could present moon phobia, and thus decrease in availability to the predators during these moon phases (Lockard and Owings, 1974; Kaufman and Kaufman, 1982; Price et al., 1984). These ideas lead us to two nonexcluding hypotheses to explain the observed pattern: (i) the melanistic individuals are more cryptic for their prey, ambushing prey more easily than other competitors on bright nights, compensating for the decrease in prey activity; (ii) poor quality foraging on bright nights did not compensate the high exposure of spotted oncillas to predators, but dark coat colour could offset this risk. Irrespective of the process underlying the observed pattern of reduction in intraspecific competition, attributed to differential use of time, our results suggest that melanistic individuals could occupy an alternative and wider ecological niche in relation to spotted individuals. While urban moths and desert rodents use melanism for cryptic protection in their habitats (Majerus, 1998; Majerus and Mundy, 2003), the oncilla, in its multicolor tropical habitat, should benefit from the variation in moonlight. These results help us to shed some light onto the way natural selection acts to maintain polymorphisms (Skúlason and Smith, 1995), in this case, melanistic forms in populations of oncillas. 


\section{Acknowledgements}

To Russel W. Coffin and FATMA for allowing field research at the Reserves. To Conservation International-Brazil, Reserva Ecológica do Caraguatá and FUNPESQUISA/ UFSC for logistical support. LGROS is supported by CNPq. NCC is a CNPq research fellow in Brazil.

\section{References}

CORDERO, GA. and NICOLAS, RA., 1987. Feeding Habits of the Opossum (Didelphis marsupialis) in Northern Venezuela. Fieldiana. Zoology, vol. 39, p. 125-132.

CARO, T., 2005. The adaptative significance of coloration in mammals. Bioscience, vol. 55, no. 2, p. 125-136. http://dx.doi. org/10.1641/0006-3568(2005)055[0125:TASOCI]2.0.CO;2.

CAROTHERS, JH. and JAKSIC, FM., 1984. Time as a niche difference: the role of interference competition. Oikos, vol. 42, no. 3, p. 403-406. http://dx.doi.org/10.2307/3544413.

DI BITETTI, MS., DI BLANCO, YE., PEREIRA, JA., PAVIOLO, A. and PEREZ, IJ., 2009. Time partitioning favors the coexistence of sympatric crab-eating foxes (Cerdocyon thous) and pampas foxes (Lycalopex gymnocercus). Journal of Mammalogy, vol. 90, no. 2, p. 479-490. http://dx.doi.org/10.1644/08-MAMM-A-113.1.

EIZIRIK, E., YUHKI, N., JOHNSON, WE., MENOTTI-RAYMOND, M., HANNAH, SS. and O'BRIEN, SJ., 2003. Molecular genetics and evolution of melanism in the cat family. Current Biology, vol. 13 , no. 5, p. 448-453. http://dx.doi.org/10.1016/S09609822(03)00128-3. PMid:12620197

ESBÉRARD, CEL., 2007. Influência do ciclo lunar na captura de morcegos Phyllostomidae. Iheringia Série Zoologia, vol. 97, no. 1, p. 81-85. http://dx.doi.org/10.1590/S0073-47212007000100012.

FORSMAN, A., AHNESJÖ, J., CAESAR, S. and KARLSSON, M., 2008. A model of ecological and evolutionary consequences of color polymorphism. Ecology, vol. 89, no. 1, p. 34-40. http:// dx.doi.org/10.1890/07-0572.1. PMid:18376544

GOULART, FVB., CÁCERES, NC., GRAIPEL, ME., TORTATO, MA., GHIZONI Jr., IR. and OLIVEIRA-SANTOS, LGR., 2009. Habitat selection by large mammals in a southern Brazilian Atlantic Forest. Mammalian Biology, vol. 74, no. 3, p. 182-190. http://dx.doi.org/10.1016/j.mambio.2009.02.006.

GRANT, BS., OWEN, DF. and CLARKE, CA., 1996. Parallel rise and fall of melanic peppered moths in America and Britain. The Journal of Heredity, vol. 87, no. 5, p. 351-357. http://dx.doi. org/10.1093/oxfordjournals.jhered.a023013

HOEKSTRA, HE. and NACHMAN, MW., 2003. Different genes underlie adaptive melanism in different populations of rock pocket mice. Molecular Ecology, vol. 12, no. 5, p. 1185-1194. http:// dx.doi.org/10.1046/j.1365-294X.2003.01788.x. PMid:12694282

JULIEN-LAFERRIÈRE, D., 1997. The Influence of moonlight on activity of woolly opossums (Caluromys philander). Journal of Mammalogy, vol. 78, no. 1, p. 251-255. http://dx.doi. org/10.2307/1382659.

KAUFMAN, DW. and KAUFMAN, GA., 1982. Effect moonlight on activity and microhabitat use by Ord's kangaroo rat (Dipodomys ordii). Journal of Mammalogy, vol. 63, no. 2, p. 309-312. http:// dx.doi.org/10.2307/1380644.

LOCKARD, RB. and OWINGS, DH., 1974. Seasonal variation in moonlight avoidance by bannertail kangaroo rats. Journal of Mammalogy, vol. 55, no. 1, p. 189-193. http://dx.doi. org/10.2307/1379266. PMid:4819590

MAJERUS, MEN., 1998. Melanism: evolution in action. Oxford: Oxford University Press.

MAJERUS, MEN. and MUNDY, NI., 2003. Mammalian melanism: natural selection in black and white. Trends in Genetics, vol. 19, no. 11, p. 585-588. http://dx.doi.org/10.1016/j.tig.2003.09.003. PMid:14585605

NACHMAN, MW., HOEKSTRA, HE. and D'AGOSTINO, SL., 2003. The genetic basis of adaptive melanism in pocket mice. Proceedings of the National Academy of Sciences of the United States of America, vol. 100, no. 9, p. 5268-5273. http://dx.doi. org/10.1073/pnas.0431157100. PMid:12704245

NOWELL, K. and JACKSON, P., 1996. Wild cats: status survey and conservation action plan. Gland: IUCN.

OLIVEIRA-SANTOS, LGR., GRAIPEL, ME., TORTATO, MA., ZUCCO, CA., CÁCERES, NC. and GOULART, FVB., 2012. Density and activity flexibility of oncilla Leopardus tigrinus (CARNIVORA, FELIDAE) in the Atlantic Forest of Southern Brazil. Zoologia. In press

OLIVEIRA, TG., TORTATO, MA., SILVEIRA, L., KASPER, CB., MAZIM, FD., LUCHERINI, M., JÁCOMO, AT., SOARES, JBG., MARQUES, RV. and SUNQUIST, M., 2010. Ocelot ecology and its effect on the small-felid guild in the lowland Neotropics. In MACDONALD, D. and LOVERIDGE, A. (Eds.). The Biology and Conservation of Wild Felid. Oxford: Oxford University Press. p.559-580.

PALOMARES, F. and CARO, TM., 1999. Interspecific killing among mammalian carnivores. American Naturalist, vol. 153, no. 5, p. 492-508. http://dx.doi.org/10.1086/303189.

PRICE, MV., WASER, NM. and BASS, TA., 1984. Effects of moonlight on microhabitat use by desert rodents. Journal of Mammalogy, vol. 65, no. 2, p. 353-356. http://dx.doi. org/10.2307/1381183.

SACCHERI, IJ., ROUSSET, F., WATTS, PC., BRAKEFIELD, PM. and COOK, LM., 2008. Selection and gene flow on a diminishing cline of melanic peppered moths. Proceedings of the National Academy of Sciences of the United States of America, vol. 105 , no. 42 , p. 16212-16217. http://dx.doi.org/10.1073/ pnas.0803785105. PMid: 18854412

SCHOENER, TW., 1967. The ecological significance of sexual dimorphism in size in the lizard Anolis conspersus. Science, vol. 155, no. 3761, p. 474-477. http://dx.doi.org/10.1126/science.155.3761.474. PMid: 17737565

SCHOENER, TW., 1974. Resource partitioning in ecological communities. Science, vol. 185, no. 4145, p. 27-39. http://dx.doi. org/10.1126/science.185.4145.27. PMid:17779277

SKÚLASON, S. and SMITH, TB., 1995. Resource polymorphisms in vertebrates. Trends in Ecology \& Evolution, vol. 10, no. 9, p. 366-370. http://dx.doi.org/10.1016/S0169-5347(00)89135-1. PMid:21237070

SWANSON, BO., GIBB, AC., MARKS, JC. and HENDRICKSON, DA., 2003. Trophic polymorphism and behavioral differences decrease intraspecific competition in a cichlid, Herichthys minckleyi. Ecology, vol. 84, no. 6, p. 1441-1446. http://dx.doi. org/10.1890/02-0353.

TORTATO, M. and OLIVEIRA, TG., 2005. Ecology of the Oncilla (Leopardus tigrinus) at Serra do Tabuleiro State Park, Southern Brazil. Cat News, vol. 42, p. 28-30. 